\title{
FIATALOK FÓRUMA
}

A Szent János Kórház és Észak-budai Egyesittett Kórházak, Traumatológiai és Kézsebészeti Osztály Budai Trauma Centrum közleménye

\section{Tossy III acromioclavicularis ízületi ficamok kétféle mútéti kezelésének összehasonlítása*}

DR. KÖNIG KÁROLY

\section{ÖSSZEFOGLALÁS}

Tossy III acromioclavicularis ficamok kétféle mútéti kezelési módszerét hasonlítottam össze retrospektív módon, osztályunkon 2010-2015 közötti időszakban operatívan kezelt sérültek két csoportján. Az összehasonlított két mútéttípus: feltárásból végzett acromioclavicularis túzés és húzóhurok felhelyezése, coracoclavicularis hurok augmentációval, lehetőség szerint a coracoclavicularis szalag varratával kiegészítve; illetve fedett acromioclavicularis dróttúzés. A kétféle eljárást a mútét hossza, szövődmények - úgymint a fémanyagok okozta lágyrészpanaszok, implantátum migráció, redislocatio, reoperáció, szeptikus szövődmények - kialakulásának gyakorisága, a radiológiai eredmény, valamint az ízület funkciója és a gyógyulás után megmaradt fájdalom mértéke alapján hasonlítottuk össze.

\section{Kulcsszavak: $\quad$ Acromioclavicularis ízület; Ficam; Vállficam;}

K. König: Comparison of two operation methods for the treatment of Tossy III acromioclavicular joint dislocations

This is a retrospective study comparing two operation methods for the treatment of AC joint dislocations using data of patients operated in our Hospital between 2010- 2015. The two operation methods: open reduction and acromioclavicular fixation by k-wire with reconstruction of the CC ligament; and closed reduction and acromioclavicular fixation by $k$ - wire. Operation time, complications, radiological and functional results and residual pain were the aspects of comparison.

Keywords: $\quad$ Acromioclavicular joint - Injuries/Surgery; Joint dislocations - Surgery/Therapy; Shoulder dislocation - Surgery;

* MTT 50. éves Jubileumi Kongresszus Fiatalok Fórumán I. díjat nyert előadás 


\section{BEVEZETÉS}

Kutatásom célja megállapítani, hogy osztályunkon Tossy III (25) acromioclavicularis (továbbiakban AC) ízületi ficamok kezelésére alkalmazott két, elvében és technikájában különböző mútéti eljárás közül melyik volt eredményesebb. Az egyik módszer a feltárásból végzett $A C$ túzés és húzóhurok felhelyezése, coracoclavicularis (továbbiakban CC) hurok augmentációval, lehetőség szerint a CC szalag varratával kiegészítve. Ennek a mútéttípusnak a lényege, hogy nem csak $A C$ rögzítést használ, hanem a clavicula stabilizálásában fontos szerepet játszó CC szalagrendszert is igyekszik helyreállítani. A másik eljárás a fedett AC tűzés, amely az egyszerűséget és gyorsaságot részesíti előnyben (1. ábra).

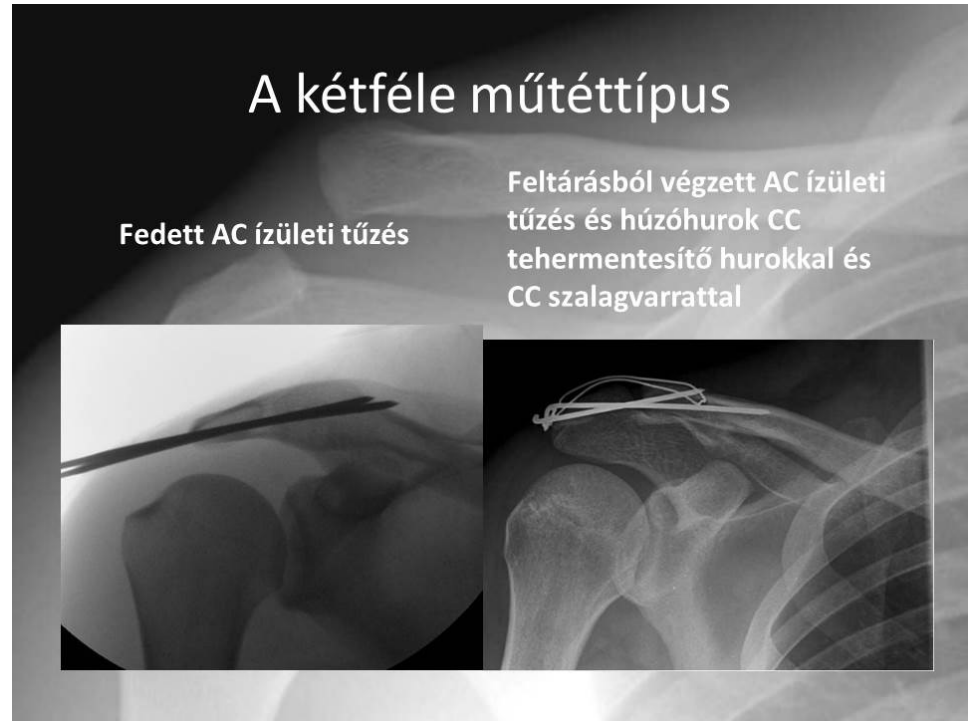

1. ábra

\section{ANYAG ÉS MÓDSZER}

Retrospektív módszerrel vizsgáltam osztályunkon 2010-2015 közötti időintervallumban a Tossy III AC ízületi ficam miatt operatívan ellátott sérültek kezelését, és annak eredményességét. $A$ fent részletezett két mútéti eljárást végeztük, mindkét betegcsoportnál varratszedésig tartó végtagkíméletet alkalmaztunk utókezelésként, majd 3 hét elteltével rehabilitációt kezdtünk.

Összesen 64 mútétet végeztünk a vizsgált időtartam alatt, ebből 19 esetben történt szalagvarrattal kiegészített beavatkozás, és 45 sérültet kezeltünk fedett tűzéssel. Az előbbi betegcsoport átlagéletkora 39 évnek adódott, utóbbiban ugyanez az érték 44 év volt. A 64 sérültből 61 férfi volt, és csak 3 nő. A jobb és bal oldali sérülések aránya közel $60 \%-40 \%$, és ez az arány mindkét betegcsoportban hasonlóan alakult.
Az összehasonlítást a következő szempontok alapján végeztem. A percben kifejezett mútét hosszt, és a szövődmények - fémanyagok okozta lágyrészpanaszok, implantátum migráció, redislocatio, reoperáció, valamint a szeptikus szövődmények - kialakulásának százalékban megadott gyakoriságát összemértem. A radiológiai eredmény értékelésére egy pontrendszert dolgoztam $\mathrm{ki}$, amelyet a fémkivétel után készült röntgenképek értékelésénél alkalmaztam. Az anatómiai helyzet 0 pontot ér, és a dislocatio mértékével az elért pontszám is növekszik, tehát minél kisebb az elért átlagpontszám, annál gyakrabban vezetett anatómiai eredményre az adott technika (2. ábra). A funkció és a gyógyulás után megmaradt fájdalom mértékének standardizált összehasonlítására az ESSSE által is jóváhagyott Constant-Murrey score-t (továbbiakban CS) $(7,8)$ alkalmaztuk a fémkivételt követően, általában 4 hónappal a mútét után. 


\section{Radiológiai értékelés}

- Anatomiai helyzet - 0 pont

- Kis dislocatio - 1 pont

- AC ízület kiszélesedése az ellenoldalhoz képest

- Fél clavicula szélességnyi ad latus dislocatio

- Közepes dislocatio - 2 pont

- Több mint fél clavicula széleségnyi de kevesebb mint

teljes csontszélességnyi ad latus dislocatio

- Nagy dislocatio - 3 pont

- Teljes clavicula szélességnyi ad latus dislocatio

\section{2. ábra}

\section{EREDMÉNYEK}

A szalagvarrattal kiegészített mútét hossza átlagosan 55 perc volt, a fedett túzés átlagosan 22 percet vett igénybe (3. ábra).

Szövődmények tekintetében azt észleltem, hogy míg feltárásból végzett beavatkozás esetében implantátum migráció, és az ebből adódó lágyrészpanaszok az esetek mindössze 10,5 és 15,8\%-ában fordultak elő, addig a fedett technikával végzett ellátásoknál ugyanezen értékek 44,4 és 42,2\%-nak adódtak. Implantátum migrációnak tekintem a beültetett fémanyagok bármilyen irányú elmozdulását, ami nem jár a rögzített csontok elmozdulásával. Meg kell jegyeznem, hogy leggyakrabban tűződrótok lateral irányú kicsúszása fordult elő, de a húzóhurkos rögzítés esetében a hurkot alkotó cerclage drót tűződrót alól történő kibújása is ide sorolandó. Az implantátum eltávolítást megelőző redislocatio csak fedett túzéses beavatkozások után fordult elö, összesen három esetben (6,7\%), ebből két sérültnél újabb traumával összefüggésben. Felületes, helyi fertőzés a feltárásból végzett mútétek után öt alkalommal (26,3\%) alakult ki, ezek azonban gyakori kötéscserével - néhány esetben peroralis antibiotikus kezeléssel kiegészítve - minden betegnél maradványtünet nélkül gyógyultak. Fedett technikánál mindössze egy alkalommal alakult ki ilyen szövődmény (2,2\%), amely szintén egyszerűen kezelhetőnek bizonyult és további komplikációt nem okozott. Feltárást igénylő szeptikus folyamat egyik technikánál sem fordult elő (I. táblázat és 4. ábra).

A fémkivételt követő röntgenvizsgálatok értékelése során az derült ki, hogy a szalagvarrattal kiegészített mútét után jelentősen kisebb volt az AC ízületi subluxatio megmaradásának gyakorisága, mint fedett tǔzés esetében (5. ábra).

A gyógyulás után megmaradt fájdalom és funkció értékelésekor megfigyelhető volt, hogy mindkét betegcsoportban a korosztálynak megfelelő átlagos CS fölötti eredményeket értek el a betegek. A feltárásból végzett beavatkozás esetében valamivel jobb lett a végeredmény, de ez a különbség minimális (6-7. ábrák). 


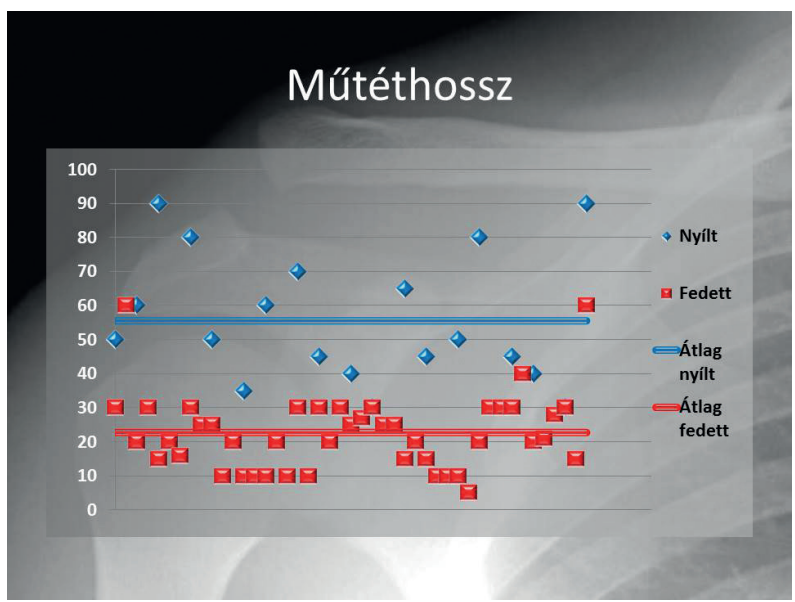

\section{3. ábra}

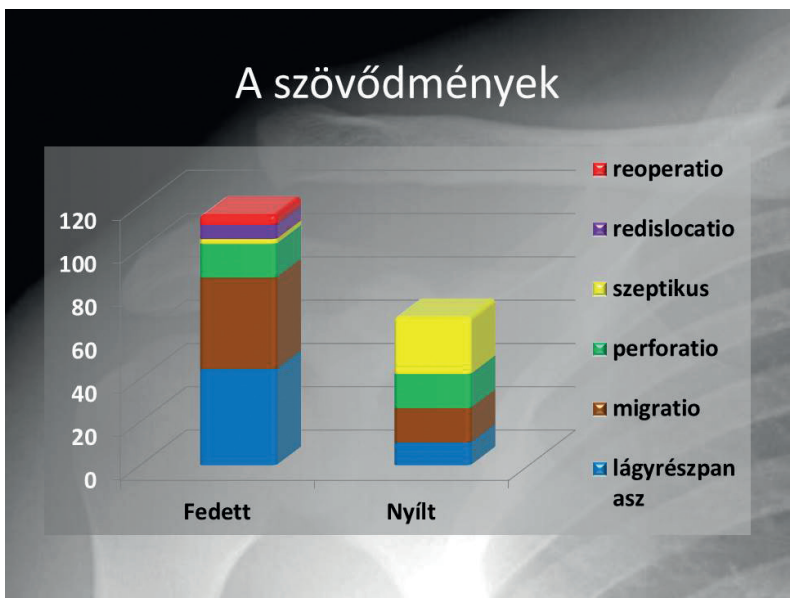

4. ábra

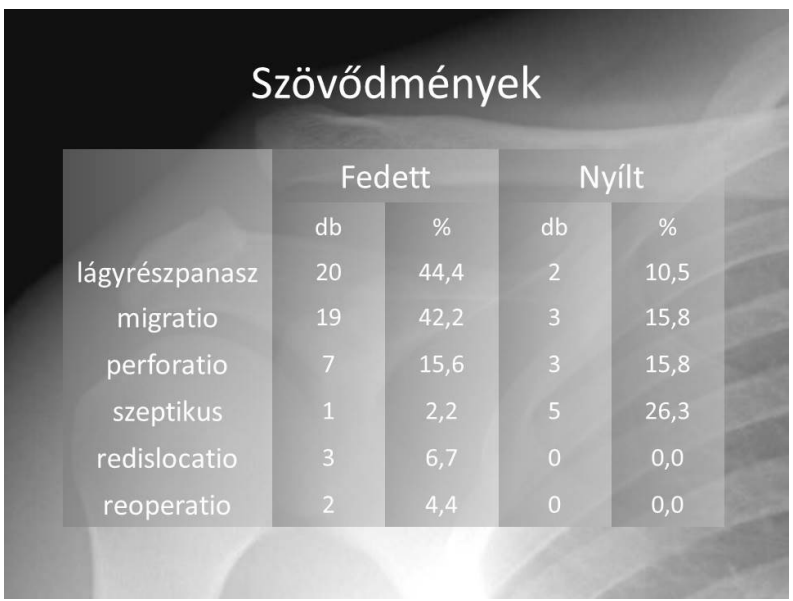

I. táblázat 


\section{Radiológiai eredmény}

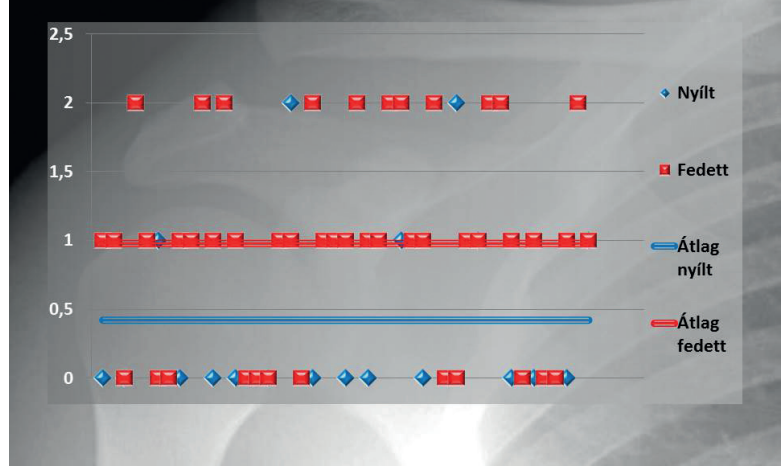

\section{5. ábra}

\section{Szalagvarrat}

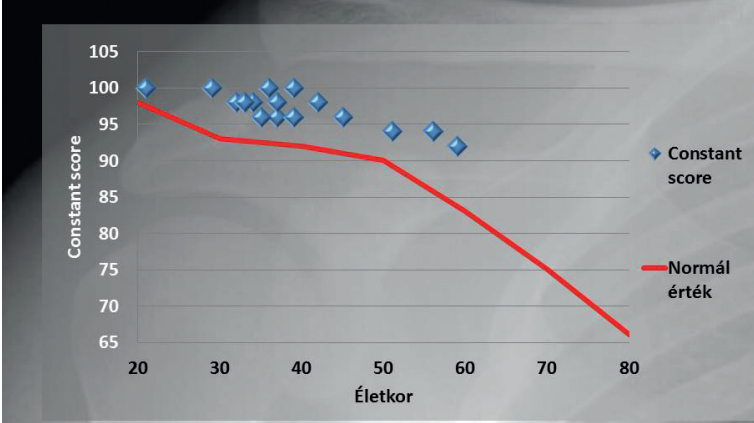

\section{6. ábra}

\section{Fedett túzés}

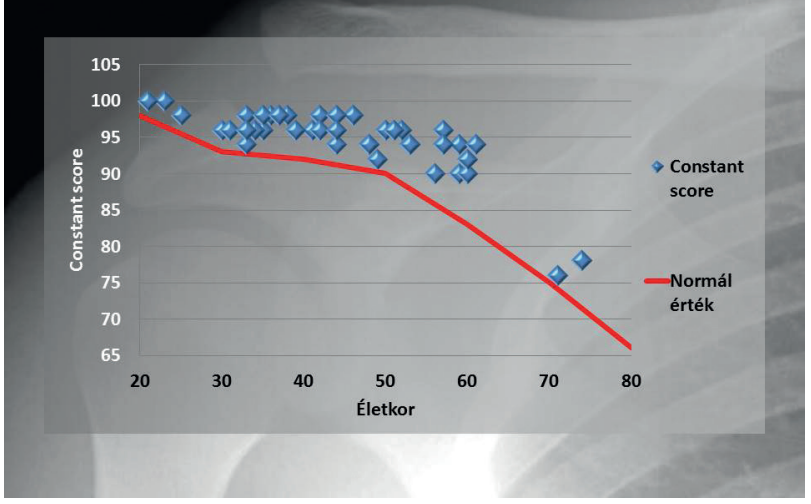

7. ábra 


\section{MEGBESZÉLÉS}

Áttekintve az ide vonatkozó nemzetközi irodalmat kiderül, hogy nincsen egyetértés a Tossy III AC ízületi ficamok kezelését illetően. Sokan megkérdőjelezik a műtéti kezelés szükségességét is $(1,2,5,6,12,13,15,17,21,22,23)$, de a mútéti eljárás típusai is nagyon sokfélék lehetnek $(3,10,11,16,20,24,27,28)$. Alapvetően megkülönböztetünk acromioclavicularis ezen belül is transarticularis és extraarticularis - valamint coracoclavicularis rögzítési módokat, és ezek kombinációit, amelyek lehetnek rigid, semirigid vagy dinamikus rögzítések (II. táblázat). Továbbá megoszlanak a vélemények az azonnali mútéti beavatkozás szükségességéről; egyes források szerint elegendő a konzervatív kezelés után panaszosan maradt eseteket halasztott operatív ellátásban részesíteni (18). Az itt felsorolt számos eltérő - az irodalom szerint a világ különböző helyein sikerrel alkalmazott - ellátási módszer létezése arra enged következtetni, hogy igazán egyik technika sem emelkedik ki a többi közül.

A hazai tudományos irodalomban olyan állásfoglalással találkoztam az AC ficamok kezelésének tekintetében (26), miszerint Rockwood (19) I-II konzervatívan (4), Rockwood IV-VI operatívan kezelendő, Rockwood III esetében pedig kezdetben konzervatív kezelés javasolt, és csak a panaszok nem szúnésének esetén indikált mútét.

Kiemelnék továbbá a hazai szakirodalomból egy, a kutatásomhoz hasonló témájú cikket (9), amelyben a kutató csoport az addig használatos, feltárásból végzett ellátás helyettesítésére kezdte alkalmazni az akkor még újdonságnak számító fedett tǔzést. A gyógyulás utáni eredményeket ugyanolyan jónak találták mindkét beavatkozásnál, de a fedett eljárás elvitathatatlan előnyeként írták le a beteg számára okozott csekélyebb megterhelést, a szeptikus szövődmény kialakulásának kisebb esélyét, valamint hogy egynapos sebészeti ellátás keretében is elvégezhető, ezáltal alacsonyabb költségekkel jár.

Olyan cikket, vagy vizsgálatot, ami pontosan az általam összehasonlított két módszert értékelné nem találtam, azonban egy cseh kutatócsoport vizsgálata szerint a CC szalagvarrattal kiegészített és nem kiegészített mútéti technikák klinikai eredményei között nincsen érdemi különbség, de hangsúlyoznám, hogy kutatásuk során csak a funkcionális eredményt értékelték (14).

A fentiek alapján arra a következtetésre jutottam, hogy szövődmények tekintetében lényegi különbség nem észlelhető a kétféle mútéttípus között, bár implantátum migráció okozta kellemetlen panaszok gyakrabban jelentkeztek fedett technikánál, helyi fertőzéses szövődmények pedig a szalagvarrattal kiegészített ellátásnál. A mútéti eljárás a feltárásból végzett beavatkozás esetében kétség kívül hosszabb és bonyolultabb, így nagyobb tapasztalatot és gyakorlatot kíván. A szalagvarrattal kiegészített technika ugyan jobb radiológiai eredményt nyújt, de úgy túnik, hogy ez a funkciót lényegében nem befolyásolja, mert mindkét vizsgált csoport hasonlóan jó funkcióval rendelkezett, és a gyógyulás után megmaradt fájdalom mértéke is egyformán alacsony volt. Az is látható, hogy eredményeim jól korrelálnak a hazai és nemzetközi szakirodalomban található, a témakörrel foglalkozó szerzők eredményivel.

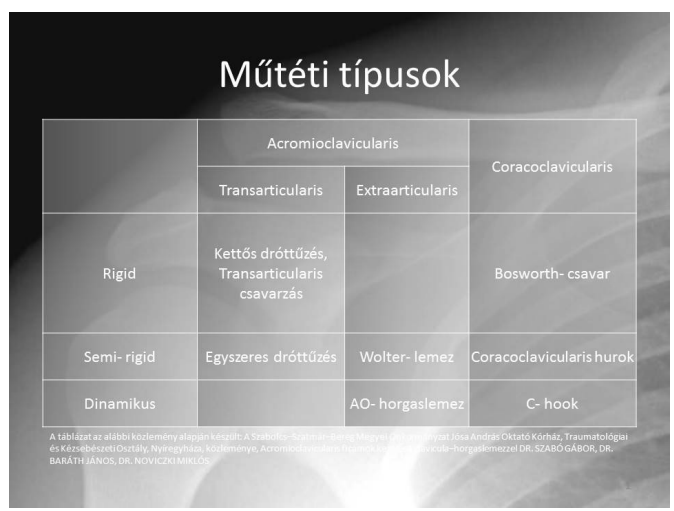

II. táblázat 


\section{IRODALOM}

1. Bannister G. C., Wallace W. A., Stableforth P. G., Hutson M. A.: The management of acute acromioclavicular dislocation. A randomized prospective controlled trial. J. Bone Joint Surg. Br. 1989. 71: 848-850.

2. Beitzel K., Cote M. P., Apostolakos J., Solovyova O., Judson C. H., Ziegler C. G., Edgar C. M., Imhoff A. B., Arciero R. A., Mazzocca A. D.: Current concepts in the treatment of acromioclavicular joint dislocations. Arthroscopy. 2013. 29. (2): 387-397. https://doi.org/10.1016/i.arthro.2012.11.023

3. Bosworth B. M.: Acromioclavicular separation: a new method of repair. Surg. Gynecol. Obstet. 1941. 76: 866-871.

4. Bogosi T.: Akut ficam konzervativ kezelése. In: Fekete A., Szabó I., Szebeni E., Zomborszky M. (Szerk.): Vállbetegségek. Kaposvár. Kaposi Mór Oktató Kórház. 2015. 147-155. p.

5. Bradley J. P., Elkousy H.: Decision making: operative versus nonoperative treatment of acromioclavicular joint injuries. Clin. Sports Med. 2003. 22. (2): 277-290. https://doi.org/10.1016/S0278-5919(02)00098-4

6. Calvo E., Lopez-Franco M., Arribas I. M.: Clinical and radiologic outcomes of surgical and conservative treatment of type III acromioclavicular joint injury. J. Shoulder Elbow Surg. 2006. 15. (3): 300-305. https://doi.org/10.1016/i.jse.2005.10.006

7. Constant C. R., Gerber C., Emery R. J., Søjbjerg J. O., Gohlke F., Boileau P.: A review of the Constant score: modifications and guidelines for its use. J. Shoulder Elbow Surg. 2008. 17. (2): 355-361. https://doi.org/10.1016/i.jse.2005.10.006

8. Constant C. R., Murley A. H.: A clinical method of functional assessment of the shoulder. Clin. Orthop. Relat. Res. 1987. 214: 160-164. https://doi.org/10.1097/00003086-198701000-00023

9. Csomor L., Széchenyi K., Fröhlich P.: Acromiclavicularis ficam kezelése percutan tüzéssel. Magyar Traumatológia Ortopédia Kézsebészet Plasztikai Sebészet. 1999. 42. Suppl. 1. 37-39.

10. Eskola A., Vainionpaa S., Korkala S., Santavirta S., Gronblad M., Rokkanen P.: Four-year outcome of operative treatment of acute acromioclavicular dislocation. J Orthop Trauma, 1991. 5. (1): 9-13. https://doi.org/10.1097/00005131-199103000-00002

11. Greiner S., Braunsdorf J., Perka C., Herrmann S., Scheffler S.: Mid to long-term results of open acromioclavicular-joint reconstruction using polydioxansulfate cerclage augmentation. Arch. Orthop. Trauma Surg. 2009. 129. (6): 735-740. https://doi.org/10.1007/s00402-008-0688-5

12. Gstettner C., Tauber M., Hitzl W., Resch H.: Rockwood type III acromioclavicular dislocation: surgical versus conservative treatment. J. Shoulder Elbow Surg. 2008. 17. (2): 220-225. https://doi.org/10.1016/i.jse.2007.07.017

13. Joukainen A., Kröger H., Niemitukia L., Mäkelä A. E., Väätäinen U.: Results of operative and nonoperative treatment of rockwood types iii and v acromioclavicular joint dislocation. A prospective, randomized trial with an 18-to 20-year follow-up. Orthop. J. Sports Med. 2014. 2. (12). 2325967114560130. https://doi.org/10.1177/2325967114560130

14. Kazda S., Pasa L., Pokorny V.: Clinical outcomes of surgical management of acromioclavicular dislocation with and without ligament suturing. Rozhl. Chir. 2011. 90. (10): 561-564.

15. Larsen E., Bjerg-Nielsen A., Christensen P.: Conservative or surgical treatment of acromioclavicular dislocation. A prospective, controlled, randomized study. J. Bone Joint Surg. Am. 1986. 68. (4): 552-555. https://doi.org/10.2106/00004623-198668040-00011

16. Nuchtern J. V., Sellenschloh K., Bishop N., Jauch S., Briem D., Hoffmann M., Lehmann W., Pueschel K., Morlock M. M., Rueger J. M., Großterlinden L. G.: Biomechanical evaluation of 3 stabilization methods on acromioclavicular joint dislocations. Am. J. Sports Med. 2013. 41. (6): 1387-1394. https://doi.org/10.1177/0363546513484892

17. Phillips A. M., Smart C., Groom A. F.: Acromioclavicular dislocation: conservative or surgical therapy. Clin. Orthop. Relat. Res. 1998. 353: 10-17. https://doi.org/10.1097/00003086-199808000-00003

18. Rolf O., Hann von Weyhern A., Ewers A., Boehm T. D., Gohlke F.: Acromioclavicular dislocation Rockwood III-V: results of early versus delayed surgical treatment. Arch. Orthop. Trauma Surg. 2008. 128. (10): 1153-1157. https://doi.org/10.1007/s00402-007-0524-3

19. Rockwood C., Matsen F. I.: Disorders of the shoulder. Philadelphia, PA: W. B. Saunders. 1990.

20. Salem K. H., Schmelz A.: Treatment of Tossy III acromioclavicular joint injuries using hook plates and ligament suture. J. Orthop. Trauma. 2009. 23. (8): 565-569. https://doi.org/10.1097/BOT.0b013e3181971b38

21. Smith T. O., Chester R., Pearse E. O., Hing C. B.: Operative versus non-operative management following Rockwood grade III acromioclavicular separation: a meta-analysis of the current evidence base. J. Orthop. Traumatol. 2011. 12. (1): 19-27. https://doi.org/10.1007/s10195-011-0127-1

22. Taft T. N., Wilson F. C., Oglesby J. W.: Dislocation of the acromioclavicular joint. An end-result study. J. Bone Joint Surg. Am. 1987. 69. (7): 1045-1051. https://doi.org/10.2106/00004623-198769070-00013

23. Tamaoki M. J., Belloti J. C., Lenza M., Matsumoto M. H., Gomes Dos Santos J. B., Faloppa F.: Surgical versus conservative interventions for treating acromioclavicular dislocation of the shoulder in adults. Cochrane Database Syst. Rev. 2010. (8): CD007429. https://doi.org/10.1002/14651858.CD007429.pub2

24. Tauber M.: Management of acute acromioclavicular joint dislocations: current concepts. Arch. Orthop. Trauma Surg. 2013. 133. (7): 985-995. https://doi.org/10.1007/s00402-013-1748-z

25. Tossy J. D., Mead N. C., Sigmond H. M.: Acromioclavicular separations: useful and practical classification for treatment. Clin. Orthop. Relat. Res. 1963. 28: 111-119. https://doi.org/10.1097/00003086-196300280-00012

26. Urbán F., Séber M.: Kezelési indikációk az evidenciák tükrében. In: Fekete A., Szabó I., Szebeni E., Zomborszky M. (Szerk.): Vállbetegségek. Kaposvár. Kaposi Mór Oktató Kórház. 2015. 171-179. 
27. Virtanen K. J., Remes V. M., Tulikoura I. T., Pajarinen J. T., Savolainen V. T., Björkenheim J. M., Paavola M. P.: Surgical treatment of Rockwood grade-V acromioclavicular joint dislocations: 50 patients followed for 15-22 years. Acta Orthop. 2013. 84. (2): 191-195. https://doi.org/10.3109/17453674.2013.775046

28. Weinstein D. M., McCann P. D., Mcllveen S. J., Flatow E. L., Bigliani L. U.: Surgical treatment of complete acromioclavicular dislocations. Am. J. Sports Med. 1995. 23. (3): 324-331. https://doi.org/10.1177/036354659502300313

\section{Dr. König Károly}

Szent János Kórház és Észak-budai Egyesített Kórházak, Traumatológiai és Kézsebészeti Osztály 1125 Budapest, Diós árok 1-3.

E-mail: konig.karoly@gmail.com 